\title{
УРОЖАЙНІСТЬ, ПЛАСТИЧНІСТЬ ТА СТАБІЛЬНІСТЬ ЯЧМЕНЮ ОЗИМОГО УЦЕНТРАЛЬНОМУ ЛІСОСТЕПУ УКРАЇНИ
}

В. М. Гудзенко

Миронівський інститут пшениці імені В. М. Ремесла НААН

Наведено результати багаторічного (2004-2012 рр.) дослідження ячменю озимого в умовах Лісостепу України. 3 використанням низки математично-статистичних методів оцінки параметрів пластичності і стабільності визначено норму реакції різних генотипів за врожайністю на контрастні гідротермічні умови вирощування. Виділено сорти, що характеризуються підвищеним рівнем врожайності та адаптивністю.

Ячмінь озимий, врожайність, норма реакиії генотипу, адаптивність, стабільність, пластичність, гомеостатичність, селекційна иінність, рейтинг адаптивності сорту

Ячмінь - одна з провідних зернових культур у світовому землеробстві. За посівними площами та валовим виробництвом зерна він поступається лише пшениці, рису і кукурудзі. Основну частину посівних площ в Україні традиційно займав ячмінь ярий - 3,5-4,0 млн. га, озимий - вирощувався на площі 300-450 тис. га [1]. Однак останніми роками намітилась тенденція до розширення посівних площ саме ячменю озимого, які збільшились у 3,5-4,0 рази (рис. 1).

Хоча південні області країни і АР Крим залишаються й на сьогодні основними регіонами вирощування ячменю озимого, проте суттєво зросли його посіви у Лісостепу. Слід зазначити, що збільшення посівів ячменю озимого і відповідно зменшення ярого, характерне і для країн західної Свропи, зокрема Франції [2]. Селекціонерами цих країн досягнуто значних успіхів у поліпшенні господарсько біологічних ознак і властивостей та морфотипу ячменю озимого в цілому. Сучасні сорти ячменю озимого фірм Secobra (Cartel, Maskara, Wintmalt, Nektaria, Salamandra), Syngenta (Winsome, Flagon, Purdey, Suzuka, Sequel), Nickerson (Cassata, Pearl), KWS (KWSCassia, Saffron) та ін., мають високий потенціал врожайності, стійкість до вилягання та хвороб [3]. Ряд сортів (Wintmalt, Maskara, Purdey, Cassata, Pearl, Winsome, Vanessa, Esterel, Cartel) відзначаються високими пивоварними властивостями, добре адаптовані до умов Західної Європи де на високих агрофонах і при достатньому рівні зволоження формують високі врожаї.

(C) В. М. Гудзенко. 2013.

ISSN 0582-5075. Селекція і насінництво. 2013. Випуск 103. 


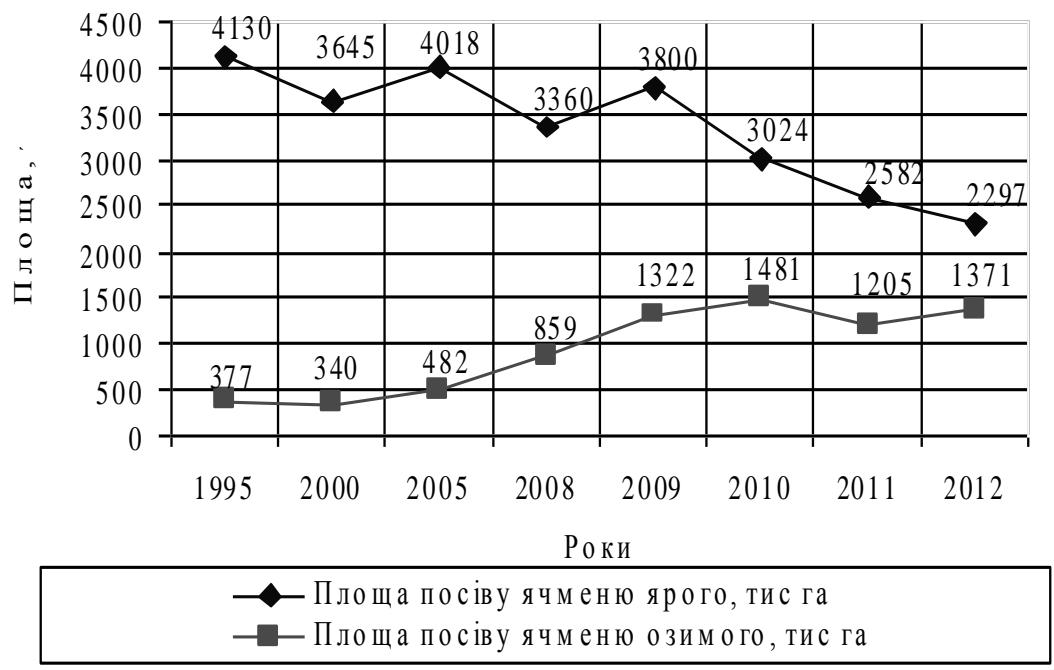

Рис. 1. Динаміка посівних площ ячменю в Україні, тис га, 1995-2012 pp.

Частина сортів ячменю озимого, що використовуються у зерновиробництві України, характеризуються нестабільністю за роками у зв'язку з низьким потенціалом врожайності, недостатньою посухостійкістю, сприйнятливістю до хвороб та схильністю до вилягання, а втрати врожаю зерна ячменю озимого від несприятливих умов перезимівлі є ще суттєвішими. Відомо, що адаптивний потенціал генотипу досить тісно пов'язаний з конкретними екологічними умовами, а тому оцінка сортів ячменю озимого у Лісостепу України є на сьогодні актуальним завданням.

Досліди закладали на полях селекційної сівозміни МІП у 20042012 рр. у відповідності до «Методики державного сортовипробування» [4]. Об'єктом досліджень були 24 генотипи ячменю озимого, створені у різні роки в селекційних установах України, Росії та Чехії. Зокрема, сорти селекції Миронівського інституту пшениці імені В. М. Ремесла НААН (МІП) Бемір 2, Радон, Миронівський 93, Рицар, Зубен, Миронівський 87, Паллідум 77, Борисфен, Ковчег, Сейм, Тутанхамон та Жерар; Селекційно-генетичного інституту - НЦНС НААН (СГІ-НЦНС) - Одеський 165, Росава, Тамань, Основа та Манас; Кримської ДСГДС НААН - Онега і Югодар, Краснодарського НДІСГ ім. П. П. Лук'яненко - Вавілон та Циклон; два сорти і селекційна лінія з Чехії (Осева Ексімпо Прага) - Kromoz, Luxor та SG-L-72. Сівбу проводили сівалкою СН-10Ц в оптимальні строки: 25 вересня - 1 жовтня. Облікова площа ділянки - $10 \mathrm{~m}^{2}$, повторність - триразова. Норма висіву 4,5 млн/га. Для поглибленої оцінки реакції генотипу на зміну умов вирощування використали одні з найбільш поширених як у вітчизняній, так і світовій селекційній практиці математично-статистичні підходи розрахунку па- 
раметрів адаптивності. Зокрема, коефіцієнт екологічної пластичності (bi) визначали за K. W. Finlay, G. N. Wilkinson [5], показник стабільності $\left(\sigma_{\text {di }}^{2}\right)$ за S. A. Eberhart, W. A. Russell [6], показники гомеостатичності (Hom) та селекційної цінності (Sc) за В. В. Хангільдіним, М. А. Литвиненком [7], загальну адаптивну здатність (ЗАЗ), варіансу специфічної адаптивної здатності $\left(\sigma^{2} \mathrm{CA}\right.$ 3i), відносну стабільність генотипу (Sgi), селекційну цінність генотипу (СЦГі), коефіцієнт компенсації-дестабілізації (Кgi) та параметри середовища, як фону для оцінки генотипів за А. В. Кільчевським, Л. В. Хотильовою [8]. Ранжирування виконували згідно з Дж. У. Снедекором [9], розрахунок рейтингу адаптивності сорту (РАС) за В. А. Власенком [10]. Детально значення кожного з параметрів адаптивності описані у названих джерелах $\mathrm{i}$ наших публікаціях [11-13]. Тому надалі зосередимось переважно на обговоренні отриманих результатів.

Погодні умови 2004-2012 pp. характеризувались контрастними гідротермічними показниками впродовж вегетації ячменю озимого, що сприяло оцінці потенціалу врожайності та норми реакції сортів на їх зміну. Про це переконливо свідчать параметри середовища (табл. 1). Найсприятливішим для росту і розвитку рослин ячменю був 2004 р., у якому досліджувані генотипи сформували найвищу середню врожайність по досліду (u+dk) - 7,50 т/га, найгіршими - 2011 р. та 2007 р. - 3,06 т/га та 3,11 т/га відповідно. Найвищою диференціюючою здатністю ( $\sigma^{2}$ ДЗСk) середовища характеризувались 2009 , 2004 та 2006 pр., найнижчою - 2008 р. Найвища відносна диференціююча здатність (Sek) відмічена у 2006-2007 pр., найнижча - у 2008 р.

Таблиця 1

Параметри середовища (року) як фону для оцінки генотипів, 2004-2012 pp.

\begin{tabular}{|l|c|c|c|c|c|c|c|}
\hline Рік & $\mathrm{u}+\mathrm{dk}$ & $\mathrm{dk}$ & $\sigma^{2}(\mathrm{GxE}) \mathrm{ek}$ & $\sigma^{2}$ ДЗСk & Lek & Sek & Kek \\
\hline 2012 & 5,05 & 1,88 & 7,86 & 21,77 & 0,36 & 9,25 & 1,77 \\
\hline 2011 & 3,06 & $-17,97$ & 7,56 & 15,50 & 0,49 & 12,87 & 1,26 \\
\hline 2010 & 3,34 & $-15,15$ & 9,73 & 16,04 & 0,61 & 11,98 & 1,30 \\
\hline 2009 & 5,66 & 8,03 & 21,89 & 49,03 & 0,45 & 12,37 & 3,99 \\
\hline 2008 & 5,62 & 7,59 & 14,51 & 10,40 & 1,39 & 5,74 & 0,85 \\
\hline 2007 & 3,11 & $-17,45$ & 21,24 & 25,10 & 0,85 & 16,10 & 2,04 \\
\hline 2006 & 4,22 & $-6,35$ & 23,03 & 45,70 & 0,50 & 16,01 & 3,72 \\
\hline 2005 & 6,34 & 14,87 & 6,94 & 20,94 & 0,33 & 7,21 & 1,70 \\
\hline 2004 & 7,50 & 26,41 & 23,78 & 48,97 & 0,49 & 9,33 & 3,98 \\
\hline
\end{tabular}

Найвищу врожайність (5,60-5,41 т/га) у середньому за 2004-2012 pр. мали сорти Тутанхамон, Жерар, Сейм та Борисфен (табл. 2). Решта відчутно поступались їм. Слід відмітити, що сорти Жерар, Тутанхамон та Борисфен відзначились і найвищим значенням максимальної врожайності за даний період $(\max =8,73-8,61 \mathrm{т} / г а)$. 
Таблиця 2

Середня врожайність, норма реакції генотипу, пластичність та стабільність сортів ячменю озимого в умовах МІП, 2004-2012 pр.

\begin{tabular}{|c|c|c|c|c|c|c|c|c|}
\hline \multirow[b]{2}{*}{ Сорт } & \multirow{2}{*}{$\begin{array}{c}\text { Уро- } \\
\text { жай- } \\
\text { ність, } \\
\text { т/га }\end{array}$} & \multicolumn{2}{|c|}{ Lim, т/га } & \multirow[b]{2}{*}{$\begin{array}{l}\mathrm{R}, \\
\mathrm{T} / \mathrm{ra}\end{array}$} & \multirow[b]{2}{*}{ Hom } & \multirow[b]{2}{*}{$\mathrm{Sc}$} & \multirow[b]{2}{*}{ bi } & \multirow[b]{2}{*}{$\sigma_{\mathrm{di}}^{2}$} \\
\hline & & $\min$ & $\max$ & & & & & \\
\hline Тутанхамон & 5,60 & 3,88 & 8,71 & 4,83 & 19,52 & 2,50 & 1,01 & 1,43 \\
\hline Жерар & 5,56 & 3,13 & 8,73 & 5,60 & 16,74 & 2,00 & 1,16 & 1,81 \\
\hline Сейм & 5,41 & 3,41 & 7,39 & 3,98 & 21,22 & 2,50 & 0,87 & 0,84 \\
\hline Борисфен & 5,40 & 2,98 & 8,61 & 5,63 & 16,73 & 1,87 & 1,07 & 3,43 \\
\hline Основа & 5,08 & 3,06 & 7,79 & 4,73 & 17,30 & 2,00 & 0,94 & 0,95 \\
\hline Паллідум 77 & 5,00 & 2,84 & 7,98 & 5,14 & 14,14 & 1,78 & 1,12 & 0,93 \\
\hline Миронівський 87 & 4,99 & 3,37 & 7,53 & 4,16 & 16,22 & 2,23 & 0,97 & 1,02 \\
\hline Миронівський 93 & 4,96 & 2,99 & 7,16 & 4,17 & 15,93 & 2,07 & 0,98 & 0,66 \\
\hline Онега & 4,94 & 2,76 & 7,57 & 4,81 & 15,14 & 1,80 & 1,02 & 0,87 \\
\hline Ковчег & 4,89 & 2,77 & 7,49 & 4,72 & 14,60 & 1,81 & 1,02 & 1,82 \\
\hline Циклон & 4,89 & 2,76 & 7,49 & 4,73 & 14,70 & 1,80 & 1,03 & 1,01 \\
\hline Kromoz & 4,89 & 2,55 & 8,20 & 5,65 & 12,21 & 1,52 & 1,24 & 1,09 \\
\hline Luxor & 4,87 & 2,79 & 8,36 & 5,57 & 12,62 & 1,62 & 1,19 & 1,26 \\
\hline Рицар & 4,85 & 3,15 & 6,54 & 3,39 & 19,11 & 2,34 & 0,77 & 1,19 \\
\hline Одеський 165 & 4,83 & 2,87 & 7,54 & 4,67 & 13,87 & 1,84 & 1,05 & 1,69 \\
\hline Манас & 4,80 & 2,93 & 6,97 & 4,04 & 15,74 & 2,02 & 0,90 & 2,01 \\
\hline Зубен & 4,80 & 1,63 & 7,93 & 6,30 & 11,91 & 0,99 & 1,19 & 3,57 \\
\hline Росава & 4,73 & 2,79 & 6,93 & 4,14 & 14,84 & 1,90 & 0,95 & 1,06 \\
\hline Югодар & 4,63 & 2,65 & 6,55 & 3,90 & 14,09 & 1,87 & 0,95 & 1,36 \\
\hline SG-L-72 & 4,58 & 2,48 & 7,49 & 5,01 & 12,47 & 1,52 & 1,07 & 0,79 \\
\hline Тамань & 4,53 & 2,59 & 7,29 & 4,70 & 12,96 & 1,61 & 0,94 & 4,98 \\
\hline Вавілон & 4,47 & 2,67 & 6,42 & 3,75 & 14,49 & 1,86 & 0,86 & 1,12 \\
\hline Радон & 4,31 & 2,83 & 7,01 & 4,18 & 13,26 & 1,74 & 0,87 & 1,42 \\
\hline Бемір 2 & 4,09 & 2,19 & 6,28 & 4,09 & 11,96 & 1,43 & 0,83 & 3,67 \\
\hline
\end{tabular}

$\mathrm{HIP}_{05} \quad 0,24$

Найширший розмах варіювання врожайності відмічено у сорту Зубен - $\mathrm{R}=6,30$ т/га, що пов'язано 3 його незадовільною перезимівлею у 2009/2010 р. і як на слідок низькою врожайністю - 1,63 т/га.

Краще співвідношення середньої врожайності та показника екологічної пластичності відмічено у сортів Тутанхамон $(5,60$ т/га, bi=1,01) і Борисфен $(5,40 \mathrm{~T} / \mathrm{ra}, \mathrm{bi}=1,07)$. Окрім названих, за середньою врожайністю суттєво переважали інші сорти: Жерар - 5,56 т/га та Сейм - 5,41 т/га. Перший був більш чутливим до покращення умов вирощування $(\mathrm{bi}=1,16)$ порівняно 3 названими, Сейм - навпаки слабше реагував на їх зміну (bi=0,87). 
Вищою стабільністю за показником середньоквадратичного відхилення теоретичних значень ознаки від фактичних $\left(\sigma_{\text {di }}^{2}=0,66-0,87\right)$ відзначились - Миронівський 93, SG-L-72, Сейм та Онега.

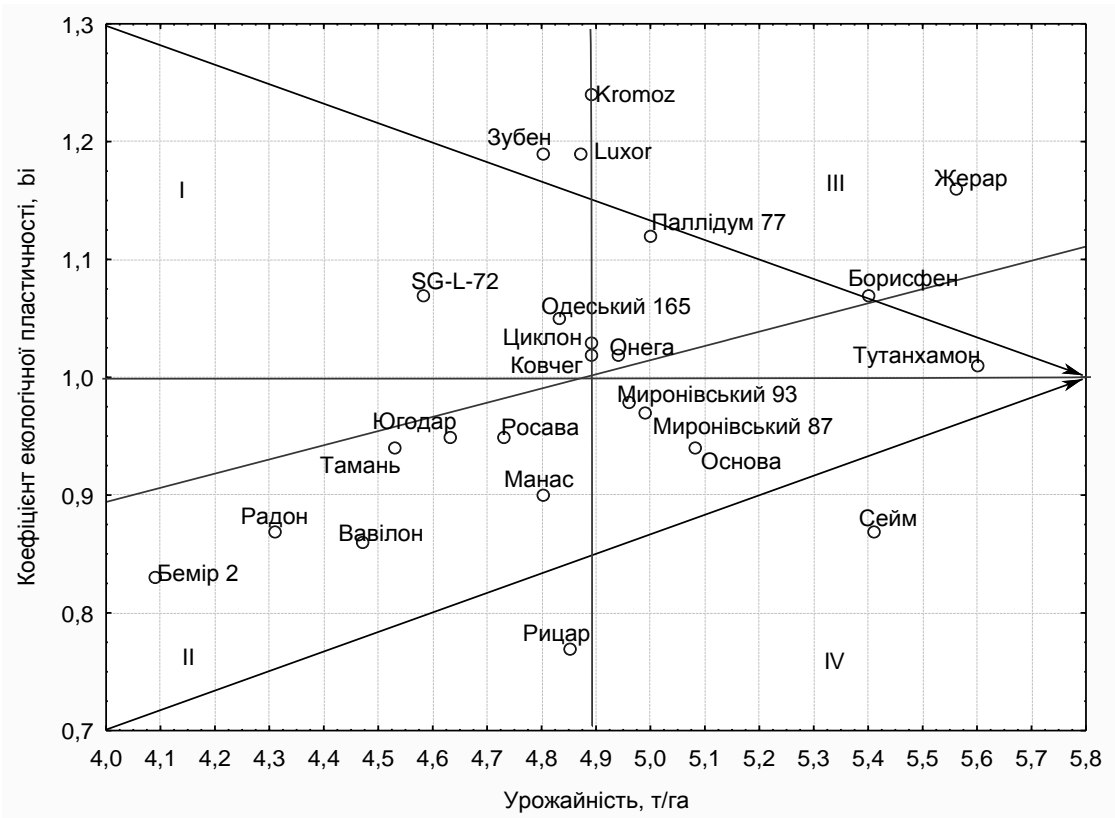

Рис. 2. Зв'язок між середньою врожайністю сортів ячменю озимого і коефіцієнтом екологічної пластичності, 2004-2012 рр.

Максимальний показник гомеостатичності (Hom) у порядку зниження мали Сейм, Тутанхамон, Рицар, Основа, Жерар та Борисфен. Найгіршими за цим параметром були Зубен, Бемір 2, Kromoz, SG-L-72 та Luxor. Поряд з параметром Нот, доцільно визначати показник селекційної цінності $(\mathrm{Sc})$, що відображає трансформовану за стабільністю врожайність. Кращими за Sc були сорти - Сейм, Тутанхамон, Рицар, Миронівський 87, Миронівський 93, Манас, Основа та Жерар.

Найвищою загальною адаптивною здатністю (ЗАЗ), що свідчить про здатність генотипу підтримувати характерну величину фенотипового прояву ознаки за різних умов, характеризувались Тутанхамон, Жерар, Сейм та Борисфен (табл. 3). Найнижча ЗАЗ відмічена у сортів Бемір 2, Радон, Вавілон, Тамань та Югодар.

За варіансою специфічної адаптивної здатності ( $\sigma^{2} \mathrm{CA}$ З $)$, яка більш інформативна у порівнянні з показником взаємодії генотип-середовище $\left(\sigma^{2}(\mathrm{GxE}) \mathrm{gi}\right)$, оскільки враховує компенсаційний ефект, кращу стабільність мали Рицар, Сейм, Вавілон, Бемір 2 та Радон. 
Таблиця 3

Параметри адаптивної здатності та стабільності сортів ячменю озимого, 2004-2012 pp.

\begin{tabular}{|l|c|c|c|c|c|c|}
\hline \multicolumn{1}{|c|}{ Сорт } & 3А3 & $\sigma^{2}(\mathrm{GxE}) \mathrm{gi}$ & $\sigma^{2} \mathrm{CA3i}$ & Sgi & СЦГі & Kgi \\
\hline Тутанхамон & 7,25 & 9,99 & 25,80 & 28,67 & 3,16 & 1,07 \\
\hline Жерар & 6,52 & 16,07 & 34,62 & 33,65 & 2,70 & 1,43 \\
\hline Борисфен & 5,26 & 22,02 & 30,42 & 32,27 & 2,75 & 1,26 \\
\hline Сейм & 5,34 & 8,52 & 18,97 & 25,45 & 3,32 & 0,78 \\
\hline Паллідум 77 & 1,20 & 8,58 & 31,15 & 35,32 & 2,32 & 1,29 \\
\hline Основа & 2,05 & 6,87 & 22,22 & 29,33 & 2,82 & 0,92 \\
\hline Онега & 0,66 & 5,39 & 26,00 & 32,61 & 2,49 & 1,07 \\
\hline Миронівський 87 & 1,12 & 6,22 & 23,50 & 30,72 & 2,66 & 0,97 \\
\hline Миронівський 93 & 0,77 & 4,03 & 23,67 & 31,05 & 2,62 & 0,98 \\
\hline Ковчег & 0,10 & 11,20 & 26,73 & 33,45 & 2,40 & 1,10 \\
\hline Циклон & 0,08 & 6,23 & 26,30 & 33,19 & 2,42 & 1,09 \\
\hline Рицар & $-0,30$ & 17,55 & 15,05 & 25,31 & 2,98 & 0,62 \\
\hline Кrотоz & 0,09 & 17,94 & 38,15 & 39,97 & 1,92 & 1,58 \\
\hline Luхог & $-0,07$ & 14,59 & 35,27 & 38,56 & 2,02 & 1,46 \\
\hline Одеський 165 & $-0,45$ & 10,54 & 28,30 & 34,81 & 2,28 & 1,17 \\
\hline Росава & $-1,48$ & 6,94 & 22,66 & 31,82 & 2,44 & 0,94 \\
\hline Манас & $-0,76$ & 14,05 & 21,40 & 30,46 & 2,58 & 0,88 \\
\hline Зубен & $-0,83$ & 28,31 & 37,20 & 40,23 & 1,86 & 1,54 \\
\hline SG-L-72 & $-2,94$ & 5,82 & 28,31 & 36,71 & 2,03 & 1,17 \\
\hline Югодар & $-2,53$ & 8,78 & 22,96 & 32,77 & 2,32 & 0,95 \\
\hline Тамань & $-3,48$ & 30,22 & 24,98 & 34,89 & 2,13 & 1,03 \\
\hline Вавілон & $-4,05$ & 10,50 & 19,00 & 30,82 & 2,38 & 0,79 \\
\hline Радон & $-5,69$ & 11,75 & 19,54 & 32,44 & 2,18 & 0,81 \\
\hline Бемір 2 & $-7,90$ & 27,47 & 19,44 & 34,11 & 1,97 & 0,80 \\
\hline
\end{tabular}

Відносна стабільність генотипу (Sgi) дозволяє порівнювати результати досліджень проведених із різними культурами та генотипами у різних умовах. По суті Sgi $є$ аналогічним коефіцієнту варіації при вивченні генотипу у різних середовищах. Найнижчу Sgi мали Рицар, Сейм, Тутанхамон та Основа. Найбільшою Sgi характеризувались Зубен, Kromoz, Luxor тa SG-L-72.

Для одночасної оцінки за потенціалом врожайності і стабільністю використовується показник селекційної цінності генотипу (СЦГі). За СЦГі кращими у порядку зниження були Сейм, Тутанхамон, Рицар, Основа, Борисфен та Жерар.

За показником компенсації-дестабілізації (Kgi), найбільш вираженим компенсуючим ефектом (Kgi=0,62-0,81) характеризувались сорти Рицар, Сейм, Вавілон, Бемір 2 та Радон, дестабілізуючим $(\mathrm{Kgi}=1,58-1,46)-\mathrm{Kromoz}$, Зубен, Luxor та Жерар. 
Розглянуті показники пластичності та стабільності характеризують різні аспекти такого складного явища, як адаптивний потенціал сорту. Тому для узагальненої оцінки адаптивності певного генотипу є необхідність розрахунку середньозваженого показника, який би якомога повніше враховував значення різних параметрів. 3 цією метою можна використати групування за допомогою непараметричної статистики, що дозволяє визначити ранги за окремими показниками і розрахувати середній ранг за їх сумою [14]. Однак, як зазначає В. А. Власенко [15], потенціал продуктивності при цьому буде врахований лише частково, як одна рівноцінна 3 поміж інших характеристик. Тому він вважає за доцільне нормувати показник середнього значення суми рангів, розділивши на нього середню врожайність. У результаті цього потенціал продуктивності стає визначальним в інтегрованому параметрі, який запропонований під терміном “рейтинг адаптивності сорту" (РАС).

Для ранжирування зразків, окрім середньої врожайності, параметрів пластичності і стабільності, ми включили також мінімальну (min) та максимальну $(\max )$ врожайність за період досліджень. Вони інформують про крайні межі реалізованого потенціалу, а тому є важливими показниками норми реакції генотипів для даних градацій лімітуючих факторів. Вищі місця у рангових рядах, за показниками - $\mathrm{x}$, $\max$ та min врожайність, 3А3, СЦГі, Hom, Sc, присвоювали сортам за їх більшого числового значення, за показниками - $\sigma^{2} \mathrm{CA3i}$, Sgi, $\sigma_{\text {di }}^{2}$ при меншому. За коефіцієнтом bi найвищий ранг надавали зразкам з bi $=1,0$, зі зниженням по мірі віддалення від 1,0 як в сторону збільшення, так і зменшення.

Перше та друге місця у рейтингу адаптивності посіли відповідно сорти Тутанхамон та Сейм (табл. 4). Відчутно поступаючись останньому за відношенням врожайності до середнього рангу, третє місце зайняв сорт Основа. Четверте місце - Миронівський 87. Місця 3 п'ятого по сьоме посіли сорти Жерар, Миронівський 93 та Борисфен, що мали близькі значення за відношенням середньої врожайності (X) до середнього рангу (Y).

3 огляду на суттєву перевагу сортів Тутанхамон та Сейм над іншими за врожайним та адаптивним потенціалом (про що свідчить відношення середньої врожайності до середнього рангу), є всі підстави стверджувати, що $з$ даного набору сортів на сьогодні вони найбільш пристосовані до мінливих умов Лісостепу України. Поступаючись двом вище названим, проте кращу порівняно з іншими адаптивність продемонстрували сорти Основа, Миронівський 87, Жерар, Миронівський 93 та Борисфен. Виділені у результаті досліджень сорти можуть бути використані як базові при розробці моделі сорту ячменю озимого для умов Лісостепу України. Не в останню чергу слід підкреслити їх цінність як джерел адаптивних ознак для залучення у схрещування. 
Таблиця 4

Ранги за врожайністю, пластичністю, стабільністю та рейтинг адаптивності сортів ячменю ярого, 2004-2012 pp.

\begin{tabular}{|c|c|c|c|c|c|c|c|c|c|c|c|c|c|c|}
\hline \multirow{2}{*}{ Сорт } & \multicolumn{11}{|c|}{ Ранги за врожайністю і параметрами адаптивності } & \multirow{2}{*}{ Y } & \multirow{2}{*}{$\mathrm{X} / \mathrm{Y}$} & \multirow{2}{*}{$\begin{array}{l}\text { Рей- } \\
\text { тинг }\end{array}$} \\
\hline & $\mathrm{X}$ & $\min$ & $\max$ & $3 \mathrm{~A} 3$ & $\sigma^{2} \mathrm{CACi}$ & Sgi & СЦГі & Hom & Sc & bi & $\sigma_{\mathrm{di}}^{2}$ & & & \\
\hline Тутанхамон & 1 & 1 & 2 & 1 & 13 & 3 & 2 & 2 & 2 & 1 & 16 & 4 & 1,40 & 1 \\
\hline Сейм & 3 & 2 & 15 & 3 & 2 & 2 & 1 & 1 & 1 & 10 & 3 & 4 & 1,38 & 2 \\
\hline Основа & 5 & 6 & 8 & 5 & 7 & 4 & 4 & 4 & 7 & 7 & 6 & 6 & 0,89 & 3 \\
\hline Миронівський 87 & 7 & 3 & 11 & 7 & 10 & 6 & 7 & 7 & 4 & 3 & 8 & 7 & 0,75 & 4 \\
\hline Жерар & 2 & 5 & 1 & 2 & 21 & 16 & 6 & 5 & 8 & 9 & 18 & 8 & 0,66 & 5 \\
\hline Миронівський 93 & 8 & 7 & 17 & 8 & 11 & 8 & 8 & 8 & 5 & 2 & 1 & 8 & 0,66 & 6 \\
\hline Борисфен & 4 & 8 & 3 & 4 & 19 & 10 & 5 & 6 & 11 & 7 & 21 & 9 & 0,61 & 7 \\
\hline Рицар & 14 & 4 & 22 & 14 & 1 & 1 & 3 & 3 & 3 & 13 & 12 & 8 & 0,59 & 8 \\
\hline Онега & 9 & 16 & 9 & 9 & 14 & 12 & 10 & 10 & 15 & 3 & 4 & 10 & 0,49 & 9 \\
\hline Манас & 16 & 9 & 19 & 16 & 6 & 5 & 9 & 9 & 6 & 8 & 20 & 11 & 0,43 & 10 \\
\hline Паллідум 77 & 6 & 11 & 6 & 6 & 20 & 20 & 16 & 15 & 17 & 8 & 5 & 12 & 0,42 & 11 \\
\hline Циклон & 12 & 17 & 13 & 12 & 15 & 14 & 12 & 12 & 16 & 4 & 7 & 12 & 0,40 & 12 \\
\hline Росава & 18 & 13 & 20 & 18 & 8 & 9 & 11 & 11 & 9 & 5 & 9 & 12 & 0,40 & 13 \\
\hline Ковчег & 10 & 15 & 12 & 10 & 16 & 15 & 13 & 13 & 14 & 2 & 19 & 13 & 0,39 & 14 \\
\hline Одеський 165 & 15 & 10 & 10 & 15 & 17 & 18 & 17 & 17 & 13 & 5 & 17 & 14 & 0,35 & 15 \\
\hline Югодар & 19 & 19 & 21 & 19 & 9 & 13 & 15 & 16 & 10 & 4 & 14 & 14 & 0,32 & 16 \\
\hline Вавілон & 22 & 18 & 23 & 22 & 3 & 7 & 14 & 14 & 12 & 11 & 11 & 14 & 0,31 & 17 \\
\hline Luxor & 13 & 14 & 4 & 13 & 22 & 22 & 21 & 20 & 19 & 10 & 13 & 16 & 0,31 & 18 \\
\hline Kromoz & 11 & 21 & 5 & 11 & 24 & 23 & 23 & 22 & 22 & 12 & 10 & 17 & 0,29 & 19 \\
\hline Радон & 23 & 12 & 18 & 23 & 5 & 11 & 18 & 18 & 18 & 9 & 15 & 15 & 0,28 & 20 \\
\hline SG-L-72 & 20 & 22 & 14 & 20 & 18 & 21 & 20 & 21 & 21 & 6 & 2 & 17 & 0,27 & 21 \\
\hline Тамань & 21 & 20 & 16 & 21 & 12 & 19 & 19 & 19 & 20 & 6 & 24 & 18 & 0,25 & 22 \\
\hline Зубен & 17 & 24 & 7 & 17 & 23 & 24 & 24 & 24 & 24 & 11 & 22 & 20 & 0,24 & 23 \\
\hline Бемір 2 & 24 & 23 & 24 & 24 & 4 & 17 & 22 & 23 & 23 & 12 & 23 & 20 & 0,21 & 24 \\
\hline
\end{tabular}


Висновки. У результаті оцінки 24 генотипів ячменю озимого в умовах Лісостепу України у 2004-2012 рр. встановлено значний розмах варіювання врожайності (від 8,73 до 1,63 т/га) у залежності від гідротермічних умов року та генетичних особливостей сорту. За рейтингом адаптивності виділено сорти Тутанхамон та Сейм, які мали найоптимальніше поєднання врожайності та показників пластичності і стабільності $з$ даного набору генотипів. Окрім них, на увагу заслуговують сорти Миронівський 87, Жерар, Миронівський 93 та Борисфен, які посіли у рейтингу адаптивності з третього по сьоме місця. Враховуючи, що сорти Тутанхамон, Сейм, Жерар, Борисфен та Основа внесені до Держреєстру України, їм слід віддавати перевагу при формуванні сортового складу в господарствах Лісостепу України, що сприятиме підвищенню та стабілізації виробництва зерна ячменю. Виділені у результаті досліджень сорти необхідно взяти за основу при розробці елементів моделі сорту ячменю озимого для умов Лісостепу України, а також залучати до гібридизації як цінні джерела адаптивних ознак.

\section{Список використаних джерел}

1. Лінчевський A. A. 92 роки селекції ячменю в Селекційно-генетичному інституті / А. А. Лінчевський // Зб. наук. праць СГІ-НЦНС. - Одеса, 2008. - Вип. 12 (52) - С. 24-49.

2. Madre M. Progress in malting barley in Secobra / M. Madre // Proceedings $9^{\text {th }}$ Intern. Genetic Symp., Brno, Czech Republic, 20-26 June 2004. - Brno, 2004. - Part 1. (Oral presentations). - P. 374-384.

3. HGCA recommended list. - winter barley 2010/11. - http://www.hgca.com.

4. Методика Державного сортовипробування сільськогосподарських культур. - Київ, 2000. - 100 с.

5. Finlay $K . W$. The analysis adaptation in a plant breeding programmed / K. W. Finlay, G. N. Wilkinson // Aust. J. Agric. Res. - 1963. - V. 14. P. $742-754$.

6. Eberhart S. A. Stability parameters for comparing varieties / S. A. Eberhart, W. A. Russel // Crop Science. - 1966. - V. 6. - P. 36-40.

7. Хангильдин В. В. Гомеостатичность и адаптивность сортов озимой пшеницы / В. В. Хангильдин, Н. А. Литвиненко // Науч.-техн. бюл. ВСГИ. 1981. - Вып. 1 (39). - С. 8-14.

8. Кильчевский $A$. В. Метод оценки адапивной способности и стабильности генотипов, диференцирующей способности среды. Сообщение I. Обоснование метода / А. В. Кильчевский, Л. В. Хотылева // Генетика. - 1985. - T. XXI. - № 9. - C. 1481-1489.

9. Снедекор Дж. У. Статистические методы в применении к исследованиям в сельском хозяйстве и биологии: Пер. с англ. В. Н. Перегудова / Дж. У. Снедекор. - М.: Сельхозиздат, 1961. - 503 с.

10. Власенко B. A. Оцінка адаптивності сортів пшениці м'якої ярої / 
В. А. Власенко // Сортовивчення та охорона прав на сорти рослин. - К.: Алефа, 2006. - С. 93-103.

11. Гудзенко B. М. Оцінка адаптивного потенціалу колекційних зразків ячменю ярого за масою зерна / В. М. Гудзенко // Зб. наук. праць ННЦ „Інститут землеробства НААН”. - К.: ВП “Едельвейс”, 2011. - Вип. 3-4. - С. 193-201.

12. Васильківський С. П. Оцінка адаптивного потенціалу ячменю ярого за продуктивною кущистістю / С. П. Васильківський, В. М. Гудзенко // Агробіологія. - 2011. - Вип. 6 (86). - С. 138-144.

13. Гудзенко B. М. Продуктивний та адаптивний потенціал ячменю ярого в умовах правобережного Лісостепу України / В. М. Гудзенко // Науковотехнічний бюлетень Миронівського інституту пшениці імені В. М. Ремесла НААН. - 2012. - Вип. 11-12. - С. 247-277. 